\title{
Philosophical Analysis on the Evolution of the Transformation in Kyrgyz Family Institute
}

\section{Venera Dzhanibekova1, Kanyshai Nurdinova1, Gulzat Amatova², Gulumbu Tokoeva², Zhamila Akmatova ${ }^{3}$, Zhypargul Abdullaeva ${ }^{*}$ (i)}

\author{
${ }^{1}$ Department of International Relations, Osh State University, Osh, Kyrgyzstan \\ ${ }^{2}$ Department of Philosophy and Political Science, Osh State University, Osh, Kyrgyzstan \\ ${ }^{3}$ Professional Foreign Languages Department, Osh State University, Osh, Kyrgyzstan \\ ${ }^{4}$ Science and Research Department, Osh State University, Osh, Kyrgyzstan \\ Email: *jypar.science@oshsu.kg
}

How to cite this paper: Dzhanibekova, V., Nurdinova, K., Amatova, G., Tokoeva, G., Akmatova, Z., \& Abdullaeva, Z. (2021). Philosophical Analysis on the Evolution of the Transformation in Kyrgyz Family Institute. Open Journal of Philosophy, 11, 35-42. https://doi.org/10.4236/ojpp.2021.111004

Received: December 17, 2020

Accepted: January 15, 2021

Published: January 18, 2021

Copyright (c) 2021 by author(s) and Scientific Research Publishing Inc. This work is licensed under the Creative Commons Attribution International License (CC BY 4.0)

http://creativecommons.org/licenses/by/4.0/

\begin{abstract}
Kyrgyz people as ancient people are going through a process that has led to several fundamental changes in their lives over the past 100 years, where the family is being transformed as an integral part. This article is describing divisions in the Kyrgyz family relations into stages by analyzing the political, socio-economical changes in society, and reveals the factors of the transformation process at each stage. The focus given to values changes during transformation in the Kyrgyz family relations and dialectical connection with other forms of society were analyzed. The family institution is the most conservative part of the social system. In the political and economic spheres of Kyrgyz society at the beginning of the 20th century and at the end of 21st century in a short period of time, there are dramatic processes of total modernization, affecting all spheres of life. There is necessity in comparison, influence of modernization processes on the Kyrgyz people family relations development and transformation within historical period, evaluation and conceptual determination of directions.
\end{abstract}

\section{Keywords}

Traditional Family, Soviet Family, Modernization, Transformation, Relative Communication System, Exogamy, Polygamy, Nuclear, Value

\section{Introduction}

The structural and functional activities in the family as a social institute were precisely proposed by sociologist Sorokin P. A. at the beginning of the twentieth century (Sorokin, 2007). Sorokin's legacy is especially relevant in the context re- 
garding values priority, the notion of the "sensate culture", ideas about family, and the moral revival vision (Uzlaner \& Stoeckl, 2018).

In the late nineteenth and early twentieth centuries, there are sharp differences in the structure of the Kyrgyz family institute; in the early twenty first century, there is transformation in the norms of behavior and the content of family roles. The process of political, socio-economic modernization in the post Soviet period over the past thirty years will determine direction of new trends. It is well known that "monogamy originated for economic reason is obliged to the victory of private property" (Marx \& Engels, 1961). Because the recent modernization processes in political, socio-economic spheres in the countries of the post Soviet Union have a direct impact on the transformation of family relations (Likhacheva et al., 2015). Under the influence of historical changes in relations between social institutes in the society, there is transformation of a family role as a social institute in modernization of social life (Kuchmaeva et al., 2009). Despite of all the crisis phenomena mentioned by scientists, the results of numerous studies show that family importance highly remains in the public mind (Sosnovskaya, 2015).

The purpose of this article is to determine the evolution of transformations in the Kyrgyz family institute in dialectical relationship with the social system, to analyze the stages of modernization processes, and to determine the synthesis of changes in family values.

Research problems in this study are:

1) Kyrgyz family relations analysis, historical development in the philosophi$\mathrm{cal}$ and typological contexts;

2) Historical and spatial analysis of political-economical transformations influences society on the Kyrgyz family institution relations;

3) Philosophical comparison and assessment of historical development stages in the Kyrgyz family relations.

\section{Findings and Discussions}

\subsection{Traditional Kyrgyz Family}

Traditional Kyrgyz family formed since the ancient times. Until the 19th and early 20th centuries, the Kyrgyz lived in marital relationship, based on the feudal-patriarchal relations. The Kyrgyz family marriage relationships structural and functional characteristics were studied and reflected in the published works (Abramzon, 1984; Kislyakov, 1969; Dzhumagulov, 1960). Information obtained from these works is based on empirical knowledge, due to the lack of written sources about the ancient Kyrgyz, folklore has served as a source of information for generations, epics such as Manas, Semetei, Seitek, Kojojash, and Zhanyl Myrza, and genealogy. The second source used materials related to the lifestyle of other nomadic and semi nomadic tribes living in Central Asia. According to the Abramzon's work "Kyrgyzs, their ethnogenetic and historical-cultural ties" (Abramzon, 1984), until the first quarter of the twentieth century, the Kyrgyz had an enlarged family form. Such enlarged family includes family members 
(parents, children) and close relatives groups (grandparents, brothers, sisters, children, and daughters-in-law). In the Abramzons work, it was noted: "Kyrgyz kinship has not only regulated by family relations, but also by social relations." Based on the Abramzons reports, the Kyrgyz system of kinship can be divided into three types: the first is the "Ata-Jurt" direction (connections from the father to the seven fathers); the second is the direction of "Taga jurt" (connections from mother to seven fathers); the third is the direction that arises as a result of the "in-law" marriage (post-marriage, kinship ties on the wife's side). By these guidelines, there are norms of behavior, which are established in the customs. For example, it is no exaggeration to say that the concepts of "big house", "big north", "big pot" in family relations lived almost until yesterday. It is not the size of the form of the object, but its attitude to the main cell in the family.

The expressions "big house", "big north", and "big pot" mean that children's parents have a joint farm in the family, and all decisions were made only by the head of the "big north". Researchers believe that this phenomenon lasted until the middle of the twentieth century, which was mentioned in several works (Dzhumagulov, 1960; Akmoldoeva, 1991). It should be noted that the above-mentioned system of "kinship" played important role in the marriage norms formation among Kyrgyz people.

Exogamy is the prohibition of intermarriage (Wilson, 2020) between relatives living in the same tribe until the seventh generation. Exogamy was existed among the first cousins of the kinship relationship. In the second direction, exogamy between siblings was milder, i.e. the possibility of marriage between sisters' children (Dzhanibekova, 2014). Based on the works of these researchers, polygamy in the Kyrgyz family has a social nature. Because the poor and the peasants followed a monogamous form of marriage (Schacht \& Bell, 2016), while the rich and the poor lived in a polygamous form of marriage (Brooks, 2009).

Abramzon noted that polygamy in the Kyrgyz people society dates back to antiquity, before the spread of Islam religion in the XVI-XVIIth centuries. Ancient monuments testify to the existence of the tradition of polygamy in the ancient Turkic tribes. However, the establishment of a Muslim ideology facilitated the development of this phenomenon. After the establishment of the socialist system of polygamy in the Kyrgyz family, the last remnants of this system eliminated in the 1930s (Achylova, 1986). The gender issue in the traditional Kyrgyz family is different from that of the peoples of Central Asia in those periods. Russian scientist diaries about travels and observations in Central Asia assess the place and role of the Kyrgyz woman. "Unlike the settled peoples of Central Asia, the Kyrgyz woman's place in the family is relatively favorable, she is not only engaged in yurt work but also sometimes engages in social activities" (Zhusupov, 1991). For example, the queen of Alay, Kurmanjan, was famous throughout Central Asia in the 19th century, she was the first and last woman who received the title "Datka" from the Kokand Kaganate, and the first "general" from the Russian emperor representative. The "child" had a special place in the formation of relations in 
the Kyrgyz family. They sought to have more children, saying that if a son expands a tribe, protects its honor and dignity, and a girl expands kinship ties. However, social inequality and low material production led to higher mortality rates in Kyrgyz families than birth. The nomadic and semi-nomadic lifestyle of the Kyrgyz, the dominance of subsistence farming in production determined the structural and functional structure of family relations in the XIXth and in the early XXth centuries, and during that period. There was a process of ethno psychological formation of family values aimed to identification.

\subsection{Soviet Kyrgyz Family}

The second stage of transformation in the Kyrgyz family relations was associated with the development of Central Asia as the Union Republic in a Soviet Socialist system after the October Revolution in 1917. Kyrgyz family relations in socialism society were studied by Soviet researchers (Mambetalieva, 1971; Achylova, 1986). Based on the above scientific research, we can prove the following conclusions about the Kyrgyz people social life structurization according to political factors modernization that led to changes in the family relations structural and functional states:

1) If in pre-socialist Kyrgyz family relations the integrity of marriage preserved through social, moral, and religious sanctions. For the first time under socialism marriage was strengthened by legal norms, marital relations become a legally established union norm. The family formed as a social institution in society and comes under the control of the government.

2) Formation of the modern form of the nuclear family begins since these times. In the Kyrgyz society, extended form of family replaced by a nuclear family form, which will unite parents and their economically dependent children: The most common forms of the nuclear family today; Couples without children (nuclear family); parents living with children (incomplete nuclear family); children of couples or one of the spouses living with parents and other relatives (complex nuclear family).

3) Under the socialist system, polygamy is not allowed in marriage, and a permanent monogamous relationship is established under the control of public institutions.

4) For the first time in the period under review, gender equality and gender policy in family relations have become relevant, and women have been given the freedom to make decisions in a marriage, education, and employment.

5) The state supervises and implements the child upbringing, education, and socialization of through bodies such as kindergartens, schools, the army, pioneers, the Komsomol, and the party.

However, the Kyrgyz family was part of the Soviet system in that period and was shaped as a means of building "socialism". The family role in society was determined in 1936-1944s by I.V. Stalin's "Family Code" defining the process of building socialism, accelerating political centralization and subordination to state ideology, and bringing the family into government full control. The relationship between men and women in each family, their integrity was monitored, 
and if there was a threat to their integrity, it was discussed at meetings on the party committee, trade union committee, the necessary decisions were made and measures were taken to persecution. Under the Communist Party, every Soviet family was obliged to the government.

Second, the solution to the gender problem was reflected in early stages of collectivization, industrialization, the Great Patriotic War, the post-war situation, women's freedom in equal work with men in fieldwork, animal farming, day and night in heavy and light industries. In Kyrgyzstan, freedom in relations between men and women is within the law, but it is limited by the socio-economic conditions of the time.

\subsection{Modern Kyrgyz Family}

By adopting the Declaration of Independence of Kyrgyzstan on August 31, 1991, the Kyrgyz Republic joins the current global processes: modernization, integration, regionalization, fragmentation, transnationalization, and globalization. The process of modernization in Kyrgyzstan is characterized by democratization in the field of political governance, the transition to a market economy. Modernization affects all spheres of public life, and it can be seen that the institution of the family is in the process of transformation as part of it. The main political, socio-economic reasons for the transformation of the traditional Kyrgyz family are:

1) The collapse of privatization and privatization reforms in the 1990s, which led to the transition of government economy to a market economy, determined the cause of the crisis in all spheres of public life (politics, governance, economics, and spiritual values) led to an appeal to the pre-industrial technologies of life. Risky implementation of privatization and privatization reforms has led to the closure and closure of industrial enterprises throughout the country, creating an unemployment crisis and instability in society.

2) The process of democratization of public administration to build a process society in Kyrgyzstan. Democracy in today's Kyrgyzstan is spontaneous and has not yet brought results. From 1990 to 2020, Kyrgyzstan experienced three coups: coups in 2005, 2010, and 2020, two inter-ethnic conflicts in 1990-2010, and several destabilizing elections. The use of ordinary people as a tool by any political group to come to power creates too much politicization of public consciousness, a conflict of values, and degradation of values.

3) The legalization of Islam after independence, which was suppressed during the Soviet era. To date, no structural norms of Islam have been defined in Kyrgyzstan in comparison with traditional and local religions. Lack of systematization of provisions in the religious sphere and lack of purpose in the interests of state security, lack of its place in public policy, various discussions of Islamic teachings among the population, the misguidance of other branches of Islam create obstacles to national identification and disrupt the daily life of the population. Religious conflict seems to exist between generations, between men and women, within the family. 
4) Increased migration flows in Kyrgyzstan since 1990s. The first stage of migration is the return of ethnic Russians to their historical homeland, and since 1995, the above-mentioned economic crisis, a new stage of migration for Kyrgyzstanis due to unemployment labor migration was registered.

\subsection{Migration Statistics}

Since the labor migration is often illegal, it is impossible to say the exact number in reality. According to the Migration Service of the Kyrgyz Republic, about 50.000 people leave the country each year. As of early $2015 \mathrm{~s}$, the 500.000 people were working in Russia, about 80.000 in the neighboring Kazakhstan, and 10.000 to 15.000 in South Korea, about 10.000 people in Turkey, and Europe, the United States, and East Asia. Today, Kyrgyzstan is Russia's third-largest workforce after Uzbekistan and Tajikistan. Another feature of labor migration in Kyrgyzstan is its feminization. Kyrgyz women who have never left their families are now migrating not only internally but mainly externally. Currently, $40 \%$ of Kyrgyz migrants in Russia are women.

According to the UNICEF, on May 17, 2019, 11\% of children in Kyrgyzstan one parent or both parents of about 277.000 children went to abroad. Women's labor migration creates a masculine aspect of genes that are not part of the Eastern tradition. The deterioration of the union of spouses (individualization leads to the autonomy of "me"). Another feature of today's labor migration is its rejuvenation. Young people leave the country to work abroad due to economic necessity before the age of 18. According to the Federal Migration Service of the Russian Federation in 2016, 18\% of registered Kyrgyz migrants were minors (Federal Migration Service raid, 2013). Street work plays a key role in the socialization of young people, freeing them from dependence on their parents.

The evolution of the transformation of Kyrgyz family relations can be summarized in Table 1.

Table 1. Evolution of transformations in the Kyrgyz family institute.

\begin{tabular}{|c|c|c|c|}
\hline $\begin{array}{l}\text { Forms in the Kyrgyz } \\
\text { family relations }\end{array}$ & $\begin{array}{l}\text { Historical conditions leading to } \\
\text { transformation in the Kyrgyz family }\end{array}$ & $\begin{array}{l}\text { Structural and functional changes in } \\
\text { family }\end{array}$ & $\begin{array}{l}\text { Dominating values in the Kyrgyz } \\
\text { family relations }\end{array}$ \\
\hline $\begin{array}{l}\text { Traditional } \\
\text { Kyrgyz family }\end{array}$ & Formation as a nation & $\begin{array}{l}\text { The feudal-patriarchal family was } \\
\text { resistant to various external influences } \\
\text { and played an important role in the } \\
\text { development of Kyrgyz's, not being } \\
\text { assimilated in a large area like other } \\
\text { peoples of Central Asia, but preserved } \\
\text { as a "nation" }\end{array}$ & $\begin{array}{l}\text { The family is regarded as a value that } \\
\text { preserves the spiritual genetic and } \\
\text { material information about the tribe } \\
\text { and is passed down from generation } \\
\text { to generation }\end{array}$ \\
\hline $\begin{array}{l}\text { Soviet Kyrgyz } \\
\text { family }\end{array}$ & $\begin{array}{l}\text { Establishment of the Soviet socialist } \\
\text { system, and monopoly of the ideology } \\
\text { of the communist party in all spheres of } \\
\text { society }\end{array}$ & $\begin{array}{l}\text { Changes in the macro social structure } \\
\text { of the family such as formation of the } \\
\text { nuclear family; pure monogamy; legally } \\
\text { approved marriage; gender equality will } \\
\text { be legalized }\end{array}$ & $\begin{array}{l}\text { Family values were in line with the } \\
\text { idea of socialism including } \\
\text { collectivism, patriotism, } \\
\text { internationalism }\end{array}$ \\
\hline
\end{tabular}




\begin{tabular}{|c|c|c|c|}
\hline $\begin{array}{l}\text { The Kyrgyz family } \\
\text { that is currently being } \\
\text { transformed }\end{array}$ & $\begin{array}{l}\text { Achieving sovereignty in Kyrgyzstan } \\
\text { lead to situations arising from the } \\
\text { process of democratization of policy; } \\
\text { the situation in the transition of the } \\
\text { economy to a market economy }\end{array}$ & $\begin{array}{l}\text { Transformation processes are taking } \\
\text { place mainly in the micro-social } \\
\text { structure of the family: decreased } \\
\text { dependence of Kyrgyz women on men; } \\
\text { the child is independent of parents from } \\
\text { an early age; reduction of the number in } \\
\text { nuclear families (in socialism there were } \\
10 \text { - } 12 \text { children in many families, today } \\
\text { there are } 5 \text { children in most families; } \\
\text { increase in extramarital sex, divorce, the } \\
\text { emergence of the male gender aspects }\end{array}$ & $\begin{array}{l}\text { Development of individual } \\
\text { independence of each family } \\
\text { member; the beginning of the } \\
\text { formation of a pragmatic approach; } \\
\text { - The establishment of "ego" } \\
\text { centrism; } \\
\text { - The beginning of the formation of } \\
\text { "social selfishness" in society }\end{array}$ \\
\hline
\end{tabular}

Table 1 shows that the family, being a relatively autonomous subsystem of society, has changed along with it. At present time, the Kyrgyz family relations are undergoing changes that have not yet stabilized under the influence of various factors, highlighting their positive and negative aspects. Family can be developed or degraded when facing the relation/bond and modernization processes.

\section{Conclusion}

The family is the structural unit of the nation and the government. Being a dialectical unity of material and spiritual-ideological relations, the family considered as a constituent element of social existence and social consciousness. Analysis of the evolution of traditional, Soviet, and modern Kyrgyz family institutes transformation performed in this work. Structural and functional state of family relation types, interpretations about traditional Kyrgyz family concepts by Abramzon, and opinions in the gender problem solution were determined. There are sharp differences in the structure of the Kyrgyz family institute. The family forms as a social institution in society and comes under the control of the government. Modernization of family relations can affect spheres of public life.

\section{Conflicts of Interest}

The authors declare no conflicts of interest regarding the publication of this paper.

\section{References}

Abramzon, S. M. (1984). Kyrgyz and Their Ethnogenetic and Historical-Cultural Ties (403 p.). Alma-Ata: Science.

Achylova, R. (1986). Family and Society(140 p.). Frunze: Kyrgyzstan.

Akmoldoeva, B. B. (1991). Features of the Way of Life of the Peoples of Central Asia and Kazakhstan: Some Questions of Archeology and Ethnography of Kyrgyzstan (pp. 42-50). Bishkek: Publishing House of Kyrgyz State University.

Brooks, T. (2009). The Problem with Polygamy. Philosophical Topics, 37, 109-122. https://doi.org/10.5840/philtopics20093727

Dzhanibekova, V. B. (2014). Discussion of Ways of Growth of Values Change in Kyrgyz Family Relations (105 p.). (Historical-Philosophical Analysis) Monograph. Osh. 
Dzhumagulov, A. (1960). Family and Marriage among the Kyrgyzs in the Chuy Valley (120 p.). Frunze.

Federal Migration Service Raid (2013). FIDH-Women and Children from Kyrgyzstan Involved in Migration (76 p.).

Kislyakov, N. A. (1969). Essays on the History of Families and Marriages among the Peoples of Central Asia and Kazakhstan (140 p.). St. Petersburg: Nauka Leningrad.

Kuchmaeva, O. V., Kuchmaev, M. G., \& Petryakova, O. L. (2009). Transformation of the Institution of the Family and Family Values. Bulletin of Slavic Cultures, 13, 20-29.

Likhacheva, A., Makarov, I., \& Makarova, E. (2015). Post-Soviet Russian Identity and Its Influence on European-Russian Relations. European Journal of Futures Research, 3, Article No. 4. https://doi.org/10.1007/s40309-015-0062-0

Mambetalieva, K. (1971). Family and Family Marriage Relations of the Kyrgyz of the Mining Industry of Kyrgyzstan: Frunze (110 p.).

Marx, K., \& Engels, F. (1961). The Origin of the Family, Private Property and the State (615 p.). Karl Marx and Frederick Engels Collected Works, Vol. 21, Moscow.

Schacht, R., \& Bell, A. (2016). The Evolution of Monogamy in Response to Partner Scarcity. Scientific Reports, 6, Article No. 32472. https://doi.org/10.1038/srep32472

Sorokin, P. A. (2007). The Main Tendencies of Our Time (416 p.). Moscow: Direct-Media.

Sosnovskaya, N. (2015). Transformation of Family Values in Modern Society. Science and Innovation, 9, 14-21.

Uzlaner, D., \& Stoeckl, K. (2018). The Legacy of Pitirim Sorokin in the Transnational Alliances of Moral Conservatives. Journal of Classical Sociology, 18, 133-153. https://doi.org/10.1177/1468795X17740734

Wilson, R. A. (2020). Rethinking Incest Avoidance: Beyond the Disciplinary Groove of Culture-First Views. Biological Theory. https://doi.org/10.1007/s13752-019-00338-2

Zhusupov, K. (1991). Kyrgyzs: Sanzhyra, History, Heritage, Custom (576 p.). Bishkek: Kyrgyzstan. 